\title{
Assessment of anti-snake venom effects of Acalypha fruticosa leaves against Indian Saw-scaled viper by using envenomed Wistar albino rats
}

\author{
Malathi Ramaswamy $^{1^{*}}$, Sivakumar Duraikannu ${ }^{2}$, Chandrasekar Solaimuthu ${ }^{3}$ \\ ${ }^{1,2,3}$ Dept. of Biotechnology, Bharathidasan University Constituent College, Perambalur, Tamil Nadu, India
}

Available online at: www.isroset.org

Received: 08/Apr/2019, Accepted: 26/May/2019, Online: 30/Jun/2019

\begin{abstract}
Indian saw-scaled viper are one of the highly venomous snake found in Indian subcontinent and its venom has a wide variety of toxic compounds and it can able to causing severe envenoming characterized by severe pharmacological effects. The traditional knowledge on the Acalypha fruticosa plant was clearly states that this plant was used against the venomous bites and stings. In best of our knowledge, there were no any scientific reports to justify the anti-snake venom potential of this plant. The main objective of the present research work was to evaluate the anti-snake venom activity of $A$. fruticosa against Indian saw-scaled viper venom using envenomed animal model. The effects of ethanolic leaves extract of A. fruticosa on hematological parameters of experimental rats, saw-scaled viper venom induced liver toxicity, renal toxicity and blood metabolites was analyzed in experimental rats. In the present study, the ethanolic leaves extract of $A$. fruticosa leaves was inhibited the venom induced changes in hematological parameters. The plant extract was effectively decreased the saw-scaled viper venom induced liver toxicity and renal toxicity in experimental rats. The observed results clearly states that the $A$. fruticosa leaves has potent snati-snake venom activity.
\end{abstract}

Keywords: Anti-snake venom, saw-scaled viper, A. fruticosa, Wistar rats, liver function markers and hematological parameters

\section{INTRODUCTION}

The snake bite envenoming comprises a significant public health problem with serious medical consequences that mainly affects rural farming populations, especially in tropical and subtropical regions. Venomous snakebite is a provincial, environmental and an occupational bio accident, rather than it is known as a 'Neglected Tropical Disease' [1]. Snake envenoming is a known as a common medical emergency encountered in the rural populations of India and it is reported that 35,000 to 50,000 people die because of venomous snakebite every year in India [2].

The snake venom is a cocktail of actively pharmacological proteins and peptides as well as low molecular weight compounds including lipids, carbohydrates and amines that target several tissues induce pain in the bitten site and different systemic disorders [3]. Viper venom is mostly rich source of metalloproteases and serine proteases which interfere with the physiological processes of victim [4]. There are 52 poisonous snakes in India, among them only 4 are considered as highly venomous and responsible for more number of deaths. The four poisonous snakes namely Indian cobra (Naja naja), saw-scaled viper (Echis carinatus), Russell's viper (Daboia russelli) and common Krait (Bangarus caeruleus) found in India are responsible for the highest death rates among the rural populations of India [5]. Echis carinatus is a highly medically important snake in India. saw-scaled viper are one of the highly venomous snake found in Indian subcontinent and its venom has a wide variety of proteins, enzymes and peptides and it can able to causing severe envenoming characterized by incoagulable blood and potentially severe systemic bleeding in victim [6].

The only available treatment for snakebite is the parenteral administration of horse or sheep derived monovalent or polyvalent antivenom or antiserum. The antivenom serum may cause potentially various side effects and its development is time consuming, expensive and requires ideal storage conditions [7]. Hence there is an urgent need of alternative approach for the finding of effective inhibitors from plant sources. Medicinal plants are a very imperative source of bioactive compounds that play a major role in the handling of venomous bites and stings, or ultimately, as supplements to conventional serum therapy. Thus, medicinal plant extracts are an expensive substitute, used either alone or in combination with other agents. Investigation on the traditional use of medicinal plants has attained significant consideration within the scientific community in recent years. 
About $25 \%$ of the drugs prescribed worldwide are come from plants [8]. In folklore remedy the plant was used in the treatment venomous bites, stings and cancer among the tribal populations in Kolli Hills, South India [9]. To the best of our knowledge, there are no any scientific reports to claim the antisnake venom activity of this plant. Hence the present research work was aimed to investigate the antisnake venom activity of $A$. fruticosa leaves against the Indian saw-scaled viper venom using animal model.

\section{MATERIALS AND METHODS}

\section{Sample collection}

The fresh plant leaves of Acalypha fruticosa was collected during the month of

November - December in 2016 at the village of Thenkuchipalayam, Villupuram district, Tamilnadu, India $\left(11.8634^{\circ} \mathrm{N}, 79.5168^{\circ} \mathrm{E}\right)$. Then the leaves was washed under running tap water to remove the dust matters and unwanted debris. Then the leaves were shade dried and powdered using mechanical grinder. The resulted fine leaf powder was stored in airtight container for further use.

\section{Plant authentication}

The collected plant specimen (Acalypha fruticosa) was scientifically identified and authenticated by Dr. S. John Britto, Director, The Rapinat Herbarium and Centre for Molecular Systematics, St. Joseph's College (Autonomous), Tiruchirappalli - 620 002, Tamilnadu, India. The voucher specimen number is DS001.

\section{Extract preparation}

The extract was prepared by adding the $20 \mathrm{~g}$ of dried and powdered plant leaves with the $100 \mathrm{ml}$ of ethanol respectively using soxhlet apparatus [10]. Then obtained extracts was stored in an air tight container at $4^{\circ} \mathrm{C}$ for further use.

\section{Collection of snake venom}

The crude venom of the Indian saw-scaled viper (Echis carinatus) venom was extracted by milking process. The saw-scaled viper snake was captured and handled by the Irula tribals (professional snake catchers) of Kurumbalur village, Perambalur district. The venom was extracted using the procedures which described by Anaswara Krishnan [11]. After the extraction, the venom was sealed in air tight container and kept in ice box to transfer it to the laboratory. The extracted crude venom was dissolved in phosphate buffer ( $\mathrm{pH}$ 7.4) and centrifuged at 3000rpm for ten minutes. The resulted supernatant was used for the experiments.

\section{In vivo studies of antisnake venom activity of Acalypha fruticosa leaves Selection of animals}

The male Wistar albino rats weighing from 210 - 230g was selected for the present research work and the same were procured from the KSR College of Arts and Science, Tiruchengode, Namakkal - 637215. The animals were maintained in the polypropylene confines beneath the lab conditions $\left(26 \pm 1{ }^{\circ} \mathrm{C}\right.$, air moisture 60 to $70 \%$, light and dark sequence were 12 hours). The animals were feed with the commercially purchased rat pelleted food with water ad libitum. The ethical clearance No: MCAS/IAEC/2019/5/5.2.2019. Every animal works was performed in the lab according to the ethical guidelines suggested by the International Animal Ethics Committee (IAEC).

\section{Experimental design to acute toxicity for dose fixing (oral administration)}

The male Wistar albino rats were divided into five groups and each group contains 4 rats. The first group (group I) was fed with standard pellet diet with water ad libitum and served as control. The remaining four groups (group II to group V) were treated with different concentration $(50-200 \mathrm{mg} / \mathrm{kg})$ of ethanolic extract of $A$. fruticosa leaves by orally for 14 days. All the animals in each group were continuously observed for 2, 4, 6 and 8 hours sequence after extract feeding to detect any changes in the behavior in relation to the posture, mood and motor activity.

\section{Experimental design to acute toxicity for dose fixing (i.p. administration)}

The male Wistar albino rats were divided into five groups and each group contains 4 rats. The first group (group I) was fed with standard pellet diet with water ad libitum and served as control. The remaining four groups (group II to group V) were injected with different concentration $(50-200 \mathrm{mg} / \mathrm{kg})$ by i.p. administration of ethanolic extract of $A$. fruticosa leaves for 14 days. All the animals in each group were continuously observed for 2, 4, 6 and 8 hours sequence after extract feeding to detect any changes in the behavior in relation to the posture, mood and motor activity.

\section{Experimental design for main study}


The male Wistar albino rats were divided into four groups and each group contains 6 rats. The group I rats were fed with standard pellet diet with water ad libitum and served as control. The group II rats were injected with $60 \mu 1 / \mathrm{ml}$ of venom suspension. The group III rats were treated with the $150 \mathrm{mg} / \mathrm{kg}$ of the extract after the injection of snake venom. The group IV rats was received the snake venom which is preincubated with the $150 \mathrm{mg} / \mathrm{kg}$ of the extract for $30 \mathrm{mins}$ at room $37^{\circ} \mathrm{C}$. All the animals in each group were continuously observed for 2, 4, 6 and 8 hours sequence after extract feeding to detect any changes in the behavior in relation to the posture, mood and motor activity.

\section{Collection of samples}

After the experimental regimen ( 4 weeks), the rats were sacrificed by cervical dislocation under mild chloroform anesthesia. Blood was collected in centrifuge tubes by an incision made in the jugular veins and serum was separated by centrifugation at $2000 \mathrm{rpm}$ for $20 \mathrm{~min}$ and utilized for various biochemical assays.

\section{HEMATOLOGICAL PARAMETERS}

\section{Determining the concentration of hemoglobin}

The $20 \mu \mathrm{l}$ of blood was added to the $5 \mathrm{ml}$ of diluent $(1: 251)$ and mixed well, then allowed to stand at room temperature for at least three minutes. The absorbance is measured at $540 \mathrm{~nm}$. A vial of hemoglobincyanide (HiCN) standard is then opened and the absorbance measured, at room temperature, in the same instrument in a similar fashion. The test sample must be analyzed within a few hours of dilution. The standard must be kept in the dark when not in use and discarded at the end of the day. The assay value of the standard is present in the vial and commonly is expressed in milligram equivalents. To convert this value to hemoglobin in grams per decilitre, the assay value is multiplied by the dilution of blood used in the test (i.e., 1:251). Consequently, an $80 \mathrm{mg}$ standard is equivalent to $20.08 \mathrm{~g} / \mathrm{dl}\left(\frac{80 \times 251}{1000}\right)$ or according to the formula. Claculation for the hemoglobin concentration

$$
\mathrm{Hb}(\mathrm{g} / \mathrm{dl})=\frac{\mathrm{A} 540 \text { test sample }}{\mathrm{A} 540 \text { standard }} \times \text { Concentration of standard }(\mathrm{mg} / \mathrm{dl})
$$

\section{Estimation of red blood cells}

The $20 \mu \mathrm{l}$ of whole blood was placed in the clean tube and then $3.98 \mathrm{ml}$ of Hayam's solution was added to the tube containing blood to get the 1:200 dilutions. The tube was mixed continuously for 3 min by mechanical shaker. Then it was taken in the neubauer chamber or counting chamber with clean and sterile cover slip. The $0.1 \mathrm{ml}$ of the diluted blood was filled to the side of the counting chamber. Once the counting chamber is filled, it was allowed to approximately 3 min for the red blood cell to settle prior to counting. Then the filled counting chamber was placed carefully on the microscope stage. Lower the condenser on the microscope and scan using the low power (10x) objective lens. The cells should be distributed evenly in all of the squares. All the cells in the in each five squares was counted using the $40 \times$ objective lens. Cells that touch the top and left lines should be counted. Cells that touch the bottom and right lines should be ignored. The count on the other side of counting chamber was repeated. The difference between the total cells counted on each side should be less than $10 \%$. The total concentration of the red blood cells were calculated using the following formula,

$$
\text { Total count }(\mathrm{Cells} / \mathrm{L})=\text { Cells counted } \times \text { dilution factor } \times 10^{6}
$$

\section{volume}

\section{Estimation of packed cell volume (Microhaematocrit)}

The anticoagulated blood was filled with capillary tubes to approximately three quarters of their length. Outside of each tube was wiped and then sealed by pushing gently into the plastic material such as Cristaseal. Most care was taken adequately, such that the clay seal has a flat surface. Then tubes were placed in microhematocrit centrifuge with the sealed end pointing outwards. Each tubes position was noted and identified. Firmly secure the inner lid of the centrifuge, and then close the outer lid. The tubes were centrifuged for five minutes at 3000rpm. The centrifuge tube was allowed standing upright to read. The length of the red cell column was measured excluding the buffy coat and to the total length. The percentage of packed cell volume was calculated by applying the following formula,

$$
\text { Hematocrit }(\%)=\text { Height of RBCs }(\mathrm{mm}) \times 100
$$

\section{Estimation of white blood cells}

The venous blood was drawn into a clean tube till the $0.5 \mathrm{ml}$ mark of WBC pipette. The WBC diluting fluid was added to 0.02 $\mathrm{ml}$ of blood with a hemoglobin pipette. Then the fluid and blood were shaken thoroughly for uniform mixture. The cover slip was placed on the counting chamber at the right place. The blood dilution mixture was shaken well and transferred to the mixture using a fine bore Pasteur pipette on to the counting chamber. The most care was taken to prevent the overflow of mixture. Then the chamber was allowed stand for two minutes to the settle down of cells to the bottom of the counting 
chamber. By using $10 \times$ or low power objective lens, the WBC was counted uniformly in four large corner squares. Before counting, the under part of the chamber was cleaned and placed on the platform of the microscope. The WBC were recognized by its retractile appearance and by the slight colour given to them by the stain contained in the diluting fluid. Cells present on the outer most line were counted on one side and the cells touching the boundary lines were not counted. The number of cells per cubic millimeter of blood was calculated using following formula,

Total cells counted $\times$ dilution factor $\times$ chamber depth

Area of the chamber counted

\section{ESTIMATION OF LIVER FUNCTION MARKER ENZYMES}

\section{Assay of aspartate aminotransferase}

The aspartate aminotransferase enzyme was assayed based on the method of Reitman and Frankel [12]. The $0.5 \mathrm{ml}$ of buffered substrate was added to the $0.1 \mathrm{ml}$ of liver homogenate and placed in a water bath at $37^{\circ} \mathrm{C}$. To the blank tubes, $0.1 \mathrm{ml}$ distilled water was added instead of liver homogenate. Exactly one hour later, 2 drops of aniline citrate reagent and $0.5 \mathrm{ml}$ of 2, 4Dinitrophenylhydrazine (DNPH) reagent were added and kept at room temperature for $20 \mathrm{~min}$. Finally, $5.0 \mathrm{ml} 0.4 \mathrm{~N}$ sodium hydroxide was added. A set of standards was also treated in the same manner and read at $520 \mathrm{~nm}$ after $10 \mathrm{~min}$. The results were expressed as IU/L of liver homogenate.

\section{Assay of alanine aminotransferase}

The alanine aminotransferase enzyme was assayed by the method of Reitman and Frankel [12]. The $0.5 \mathrm{ml}$ of buffered substrate was added to $0.1 \mathrm{ml}$ of liver homogenate and placed in a water bath at $37^{\circ} \mathrm{C}$. To the blank tubes, $0.1 \mathrm{ml}$ distilled water was added instead of liver homogenate and served as blank. Exactly one hour later, 2 drops of aniline citrate reagent and $0.5 \mathrm{ml}$ of 2, 4-Dinitrophenylhydrazine (DNPH) reagent were added and kept at room temperature for $20 \mathrm{~min}$. Finally, $5.0 \mathrm{ml}$ of $0.4 \mathrm{~N}$ sodium hydroxide was added. A set of standards was also treated in the same manner and read at $520 \mathrm{~nm}$ after 10 min. The results were expressed as IU/L of liver homogenate.

\section{Estimation of acid phosphatase}

The acid phosphatase enzyme was assayed by the method of King and Armstrong [13]. The $4 \mathrm{ml}$ of the buffered substrate was pipette out and taken into a test tube and incubated at $37^{\circ} \mathrm{C}$ for $5 \mathrm{~min}$. Then $0.2 \mathrm{ml}$ of sample was added and incubated for 60 min and removed then immediately $1.8 \mathrm{ml}$ of diluted phenol reagent was added. At the same time a control was set up which containing $4 \mathrm{ml}$ buffered substrate and $0.2 \mathrm{ml}$ of sample to which $1.8 \mathrm{ml}$ of phenol reagent was added immediately. Then it was mixed well and centrifuged. The $4 \mathrm{ml}$ of the supernatant was added into the $2 \mathrm{ml}$ of sodium carbonate. Then $4 \mathrm{ml}$ of working standard solution was taken and for blank taken $3.2 \mathrm{ml}$ water and $0.8 \mathrm{ml}$ of phenol reagent was taken. Then $2 \mathrm{ml}$ of sodium carbonate was added. All the tubes were incubated at $37^{\circ} \mathrm{C}$ for $15 \mathrm{~min}$. The colour development was measured at $700 \mathrm{~nm}$. The activity in tissue homogenate was expressed as $\mu$ moles of phenol liberated $/ \mathrm{min} / \mathrm{mg}$ protein.

\section{Assay of $\gamma$-glutamyl transferase}

The activity of $\gamma$-glutamyl transferase was estimated by the method of Rosalki [14]. The $0.05 \mathrm{ml}$ of liver homogenate was made up to $0.5 \mathrm{ml}$ by the addition of L- $\gamma$-glutamyl-p-nitroanilide substrate and was incubated at $37^{\circ} \mathrm{C}$ for $30 \mathrm{~min}$. The standard tubes taken at a concentration ranging from 0.1 to $0.4 \mu$ mole were also incubated as above. The reaction was arrested by the addition of $2.5 \mathrm{ml}$ of $10 \%$ acetic acid. Simultaneously, a control without serum was also subjected to the above treatment and incubation excepting that serum was added after arresting the reaction. The yellow colour developed after the addition of acetic acid was measured at $410 \mathrm{~nm}$ against the blank using spectrophotometer. The activity of $\gamma$-GT was expressed as IU/L of serum.

\section{Estimation of alkaline phosphatase}

The alkaline phosphatase enzyme was estimated using the diagnostic kit based on the method of Kind and King [15]. The reaction mixture was containing the $1 \mathrm{ml}$ of buffered substrate, $3.1 \mathrm{ml}$ of deionised water and $0.1 \mathrm{ml}$ of liver homogenate, and it was incubated at $37^{\circ} \mathrm{C}$. Exactly after $15 \mathrm{~min}, 2 \mathrm{ml}$ of color reagent was added to all the tubes. The control tubes received the enzyme after the addition of color reagent. $0.1 \mathrm{ml}$ of standard and $0.1 \mathrm{ml}$ of distilled water (blank) were also treated simultaneously and the color developed was read at $510 \mathrm{~nm}$. The enzyme activity was expressed as IU/L of plasma.

\section{Assay of lactate dehydrogenase}

The activity of lactate dehydrogenase (LDH) was assayed by the method of Varley [16]. To a set of tubes, $1 \mathrm{ml}$ of the buffered substrate and $0.1 \mathrm{ml}$ of tissue homogenate was added and the tubes were incubated at $37^{\circ} \mathrm{C}$ for $15 \mathrm{~min}$. After adding $0.2 \mathrm{ml}$ of NAD solution, the incubation was continued for another $15 \mathrm{~min}$. The reaction was then stopped by adding $1 \mathrm{ml}$ of 2, 4Dinitrophenylhydrazine (DNPH) reagent and the tubes were incubated for $15 \mathrm{~min}$ at $37^{\circ} \mathrm{C}$. The $0.1 \mathrm{ml}$ of tissue homogenate 
was added to blank tubes after stopping the reaction with 2, 4-Dinitrophenylhydrazine (DNPH). The $7 \mathrm{ml}$ of $\mathrm{NaOH}$ solution was added and the colour developed was measured at $420 \mathrm{~nm}$. Stable aliquots of the standard were also analyzed by the same procedure. The enzyme activity was expressed in IU/L.

\section{ESTIMATION OF RENAL FUNCTION MARKERS}

\section{Estimation of uric acid}

To the $1 \mathrm{ml}$ of the enzyme reagent, $25 \mu \mathrm{l}$ of serum was added and mixed by inversion. $25 \mu \mathrm{l}$ of standard and $25 \mu \mathrm{l}$ of distilled water (blank) also processed simultaneously. The tubes were incubated at $37^{\circ} \mathrm{C}$ for 5 min and the color developed was read at $510 \mathrm{~nm}$. The values were expressed as $\mathrm{mg} / \mathrm{dL}$ of plasma and urine.

\section{Estimation of creatinine}

For the estimation of creatinine, to $1 \mathrm{ml}$ of working reagent, $100 \mu \mathrm{l}$ of serum or working standard was added and a stopwatch was started. Initial absorbance, Ao, was read exactly after 30 seconds of adding test and standard. Absorbance, A1, for test and standard was read exactly after 60 seconds of adding test and standard to the working reagent. Creatinine content in serum was calculated as:

$$
\begin{gathered}
\text { Where, } \Delta \mathrm{AT}=\mathrm{A} 1 \mathrm{~T}-\mathrm{AoT} \\
\Delta \mathrm{AS}=\mathrm{A} 1 \mathrm{~S}-\mathrm{AoS}
\end{gathered}
$$

\section{Estimation of blood urea nitrogen (BUN)}

The blood urea nitrogen enzyme reagent was reconstituted according to the manufacturer's instructions. The $1.5 \mathrm{ml}$ of blood urea nitrogen (BUN) enzyme reagent was pipetted into each of the labeled test tubes and was incubated at room temperature. To the above solution $10 \mu \mathrm{l}$ of sample was added and mixed gently. Deionized water was used instead of the sample for the reagent blank and standard BUN solution was used instead of the sample for standard. All the tubes were incubated for five minutes at $37^{\circ} \mathrm{C}$. Then, $1.5 \mathrm{ml}$ blood urea nitrogen (BUN) color developer was added and mixed gently. The absorbance of the standard and test sample was measured against the blank at a wavelength of $630 \mathrm{~nm}$. The blood urea nitrogen (BUN) content in serum was calculated as:

$$
\text { BUN }(\mathrm{mg} / \mathrm{dl})=\text { Absorbance of sample } / \text { Absorbance of standard } \times \text { Conc. of standard }(\mathrm{mg} / \mathrm{dl})
$$

\section{Statistical analysis}

All the results obtained in this investigation were subjected to statistical analysis. The significance of the data among control and experimental groups were derived at 5\% level using the (Duncan's multiple range) DMR test, and is represented in the respective tables. Results were analyzed statistically by one-way analysis of variance (ANOVA) followed by Tukey's multiple comparison using statistical package for social sciences (SPSS) software student's version. The difference was considered significant if $\mathrm{p}<0.005$.

\section{RESULTS}

\section{Acute toxicity studies of plant extract for dose fixing}

\section{Effect of ethanolic extract of $\boldsymbol{A}$. fruticosa leaves on hematological parameters of rats (oral administration)}

The result of acute toxicity study was showed that there were a no any significant $(\mathrm{p}<0.005)$ changes or very mild changes in blood components with up to $150 \mathrm{mg} / \mathrm{kg}$ concentration of the extract when compared to the control. The $200 \mathrm{mg} / \mathrm{kg}$ of the extract showed a significant $(\mathrm{p}<0.005)$ decrease in relative blood components (Table 1). Hence, it was clear that up to the $150 \mathrm{mg} / \mathrm{kg}$ of the extract does not show any toxicity in experimental rats. For this reason the $150 \mathrm{mg} / \mathrm{kg}$ of the extract was selected as an optimum dose for this study.

Table 1: Effect of ethanolic extract of $A$. fruticosa leaves leaves on hematological parameters of control and experimental rats (oral administration)

\begin{tabular}{|l|c|c|c|c|}
\hline \multicolumn{1}{|c|}{ Groups/Treatment } & Haemogloblin $(\mathbf{g m} / \mathbf{d l})$ & $\mathbf{P C V}(\boldsymbol{\%})$ & $\mathbf{R B C}\left(\mathbf{1 0}^{\mathbf{1 2}} / \boldsymbol{\mu l}\right)$ & $\mathbf{W B C}\left(\mathbf{1 0}^{\mathbf{3}} / \boldsymbol{\mu l}\right)$ \\
\hline Control & $14.00 \pm 1.07$ & $42.01 \pm 0.84$ & $4.60 \pm 0.35$ & $6.5 \pm 0.32$ \\
\hline $\begin{array}{l}\text { Plant extract } \\
(50 \mathrm{mg} / \mathrm{kg} \text { bw })\end{array}$ & $14.13 \pm 1.08$ & $42.03 \pm 0.78$ & $4.63 \pm 0.35$ & $6.5 \pm 0.25$ \\
\hline Plant extract & $14.29 \pm 1.09$ & $42.16 \pm 1.17$ & $4.65 \pm 0.36$ & $6.5 \pm 0.41$ \\
\hline
\end{tabular}




\begin{tabular}{|l|c|c|c|c|}
\hline$(100 \mathrm{mg} / \mathrm{kg} \mathrm{bw})$ & & & \\
\hline $\begin{array}{l}\text { Plant extract } \\
(150 \mathrm{mg} / \mathrm{kg} \mathrm{bw})\end{array}$ & $14.36 \pm 1.09^{*}$ & $42.13 \pm 0.73^{*}$ & $4.70 \pm 0.36^{*}$ & $6.6 \pm 0.36^{*}$ \\
\hline $\begin{array}{l}\text { Plant extract } \\
(200 \mathrm{mg} / \mathrm{kg} \mathrm{bw})\end{array}$ & $13.60 \pm 0.43^{\mathrm{ns}}$ & $41.26 \pm 1.24^{\mathrm{ns}}$ & $3.00 \pm 0.23$ & $6.7 \pm 0.23^{\mathrm{ns}}$ \\
\hline
\end{tabular}

Values are expressed as mean \pm SD of four animals in each group $(\mathrm{p}<0.005)$

Statistical comparison: Group II, III, IV and V vs Group I

* - Significant $(\mathrm{p}<0.005)$, ns - not significant

Effect of ethanolic extract of $A$. fruticosa leaves on hematological parameters of rats (i.p. administration)

In this result also showed that there were a no any significant $(p<0.005)$ changes or very mild changes in blood components with up to $150 \mathrm{mg} / \mathrm{kg}$ concentration of plant extract when compared to the control. The $200 \mathrm{mg} / \mathrm{kg}$ of plant extract showed a significant $(\mathrm{p}<0.005)$ decrease in relative blood components (Table 2). Hence, it was clear that up to the $150 \mathrm{mg} / \mathrm{kg}$ of plant extract does not show any toxicity in experimental rats. For this reason the $150 \mathrm{mg} / \mathrm{kg}$ of plant extract was selected as an optimum dose.

Table 2: Effect of ethanolic extract of $A$. fruticosa leaves on hematological parameters of control and experimental rats (i.p. administration)

\begin{tabular}{|l|c|c|c|c|}
\hline Groups/Treatment & Haemogloblin $(\mathbf{g m} / \mathbf{d l})$ & $\mathbf{P C V}(\boldsymbol{\%})$ & $\mathbf{R B C}\left(\mathbf{1 0}^{\mathbf{1 2}} / \boldsymbol{\mu l}\right)$ & $\mathbf{W B C}(\mathbf{1 0} / \boldsymbol{\mu l})$ \\
\hline Control & $14.00 \pm 1.07$ & $42.01 \pm 3.20$ & $4.60 \pm 0.35$ & $6.5 \pm 0.35$ \\
\hline $\begin{array}{l}\text { Plant extract } \\
(50 \mathrm{mg} / \mathrm{kg} \mathrm{bw})\end{array}$ & $14.00 \pm 1.08$ & $42.02 \pm 3.21$ & $4.60 \pm 0.35$ & $6.5 \pm 0.25$ \\
\hline $\begin{array}{l}\text { Plant extract } \\
(100 \mathrm{mg} / \mathrm{kg} \mathrm{bw})\end{array}$ & $14.01 \pm 1.08$ & $42.01 \pm 3.22$ & $4.61 \pm 0.35$ & $6.6 \pm 0.41$ \\
\hline $\begin{array}{l}\text { Plant extract } \\
(150 \mathrm{mg} / \mathrm{kg} \text { bw) }\end{array}$ & $14.03 \pm 1.09^{*}$ & $41.03 \pm 3.23^{*}$ & $4.34 \pm 0.36^{*}$ & $6.6 \pm 0.36^{*}$ \\
\hline $\begin{array}{l}\text { Plant extract } \\
(200 \mathrm{mg} / \mathrm{kg} \mathrm{bw})\end{array}$ & $12.60 \pm 0.43^{\mathrm{ns}}$ & $39.54 \pm 3.24^{\mathrm{ns}}$ & $3.00 \pm 0.23^{\mathrm{ns}}$ & $6.8 \pm 0.23^{\mathrm{ns}}$ \\
\hline
\end{tabular}

Values are expressed as mean \pm SD of four animals in each group $(\mathrm{p}<0.005)$

Statistical comparison: Group II, III, IV and V vs Group I

* - Significant $(\mathrm{p}<0.005)$, ns - not significant

Effects of ethanolic extract of $A$. fruticosa leaves on hematological parameters of control and experimental rats The snake venom $(60 \mu \mathrm{l} / \mathrm{ml})$ administered group of rats showed the significant $(\mathrm{p}<0.005)$ decrease in $\mathrm{RBC}$ and hemoglobin while it increases the level of WBC. The treatment with snake venom which is preincubated with the extract $(150 \mathrm{mg} / \mathrm{kg})$ for 30 min was significantly $(\mathrm{p}<0.005)$ restored the blood components in the experimental rats which decreased by the snake venom. The oral administration of the extract also showed a significant $(\mathrm{p}<0.005)$ increase in the blood components $($ Table 3$)$. This results clearly exhibits that the extract was effectively neutralized the lethal effect of snake venom.

Table 3: Levels of haemoglobin, $\mathrm{RBC}$ and $\mathrm{WBC}$ of control and experimental rats

\begin{tabular}{|l|c|c|c|c|}
\hline Groups/Treatment & Haemoglobin $(\mathbf{g m} / \mathbf{d l})$ & PCV $(\boldsymbol{\%})$ & $\mathbf{R B C}\left(\mathbf{1 0}^{\mathbf{1 2}} \boldsymbol{\mu l}\right)$ & WBC $\left(\mathbf{1 0}^{\mathbf{3}} \boldsymbol{\mu l}\right)$ \\
\hline Control & $14.30 \pm 1.09$ & $38.29 \pm 2.92$ & $4.21 \pm 0.32$ & $6.5 \pm 0.35$ \\
\hline Venom $(60 \mu \mathrm{l} / \mathrm{ml})$ & $7.69 \pm 0.59$ & $19.06 \pm 1.45$ & $2.10 \pm 0.16$ & $8.9 \pm 0.26$ \\
\hline Venom + extract (Oral) & $10.76 \pm 0.82^{\text {ns }}$ & $29.33 \pm 2.25$ & $3.38 \pm 0.26$ & $7.2 \pm 0.63^{\mathrm{ns}}$ \\
\hline Venom + extract (i.p.) & $13.72 \pm 1.04^{*}$ & $35.10 \pm 2.67$ & $3.90 \pm 0.30^{*}$ & $6.9 \pm 0.78^{*}$ \\
\hline
\end{tabular}

Values are expressed as mean \pm SD of four animals in each group $(\mathrm{p}<0.005)$

Statistical comparison: Group II, III, IV and V vs Group I 
* - Significant $(\mathrm{p}<0.005)$, ns - not significant

Effects of ethanolic extract of $\boldsymbol{A}$. fruticosa leaves on liver function marker enzymes of control and experimental rats

The snake venom $(60 \mu \mathrm{l} / \mathrm{ml})$ injected group of rats resulted the significant $(\mathrm{p}<0.005)$ reduction in liver function marker enzymes such as aspartate transaminase, alanine transaminase, alkaline phosphatase and gamma glutamine transferase in contrast to the control group. Whereas, the treatment the snake venom which is preincubated with the with the ethanolic extract of A. fruticosa leaves $(150 \mathrm{mg} / \mathrm{kg})$ at room temperature for $30 \mathrm{~min}$ was significantly $(\mathrm{p}<0.005)$ increase and restored the liver function marker enzymes like, aspartate aminotransferase (AST), alanine aminotransferase (ALT), alkaline phosphatase (ALP), acid phosphatase (ACP), gamma glutamyl transferase $(\gamma-\mathrm{GT})$ and lactate dehydrogenase (LDH) level in experimental rats (Table 4) which in contrast to the venom administered group. The administration of $150 \mathrm{mg} / \mathrm{kg}$ of ethanolic extract of $A$. fruticosa leaves by oral administration was also possessed the significant $(\mathrm{p}<0.005)$ increase in the liver function markers. This result was clearly demonstrates that the administration of the extract was effectively inhibited the liver toxicity which is induced by the saw-scaled viper venom.

Table 4: Levels of liver function marker enzymes of control and experimental rats

\begin{tabular}{|l|c|c|c|c|c|c|}
\hline $\begin{array}{c}\text { Groups/ } \\
\text { Treatment }\end{array}$ & AST (IU/dl) & ALT (IU/dl) & $\gamma-G T(I U / d l)$ & ACP (IU/dl) & ALP (IU/dl) & LDH (IU/dl) \\
\hline Control & $782.13 \pm 59.56$ & $155.03 \pm 11.80$ & $190.03 \pm 14.47$ & $19.00 \pm 1.45$ & $240 \pm 18.28$ & $630.11 \pm 47.98$ \\
\hline $\begin{array}{l}\text { Venom } \\
(60 \mu l / m l)\end{array}$ & $436.07 \pm 33.21$ & $104.02 \pm 7.92$ & $138.02 \pm 10.51$ & $9.00 \pm 0.69$ & $175.09 \pm 9.29$ & $458.08 \pm 34.88$ \\
\hline $\begin{array}{l}\text { Venom + } \\
\text { extract (oral) }\end{array}$ & $567.09 \pm 43.18$ & $131.07 \pm 10.03$ & $177.03 \pm 13.55$ & $14.01 \pm 1.07^{\mathrm{ns}}$ & $213.11 \pm 16.31^{\mathrm{ns}}$ & $549.27 \pm 42.04$ \\
\hline $\begin{array}{l}\text { Venom + } \\
\text { extract (i.p) }\end{array}$ & $607.30 \pm 46.48^{*}$ & $145.02 \pm 11.04$ & $182.03 \pm 13.86^{*}$ & $17.00 \pm 1.29$ & $226.04 \pm 17.21^{*}$ & $590.10 \pm 44.93^{*}$ \\
\hline
\end{tabular}

Values are expressed as mean \pm SD of four animals in each group $(\mathrm{p}<0.005)$

Statistical comparison: Group II, III, IV and V vs Group I

* - Significant $(\mathrm{p}<0.005)$, ns - not significant

Effects of ethanolic extract of $\boldsymbol{A}$. fruticosa leaves on renal function markers of control and experimental rats

The snake venom $(60 \mu \mathrm{l} / \mathrm{ml})$ administered group of rats showed the significantly $(\mathrm{p}<0.005)$ increased level of renal function markers such as, blood urea nitrogen (BUN), creatinine and uric acid when compared to the control (Table 5). The injection of snake venom which is preincubated with the ethanolic extract of A. fruticosa leaves (150mg/kg) for $30 \mathrm{~min}$ at room temperature was exhibited the significantly $(\mathrm{p}<0.005)$ reduced the renal function markers level in experimental rats when compared to the venom administered group. The treatment with the $150 \mathrm{mg} / \mathrm{kg}$ of ethanolic extract of $A$. fruticosa leaves by oral administration was also possessed the significant $(\mathrm{p}<0.005)$ reduction in the renal function markers. This result was clearly indicates that the extract was effectively counter acted the renal toxicity which is induced by the saw-scaled viper venom.

Table 5: Levels of renal function markers of control and experimental rats

\begin{tabular}{|l|c|c|c|}
\hline \multicolumn{1}{|c|}{ Groups/Treatment } & BUN (mg/dl) & Creatinine (mg/dl) & Uric Acid (mg/dl) \\
\hline Control & $21.40 \pm 1.63$ & $0.50 \pm 0.04$ & $6.20 \pm 0.62$ \\
\hline Venom $(60 \mu \mathrm{l} / \mathrm{ml})$ & $32.21 \pm 2.45$ & $0.73 \pm 0.03$ & $9.30 \pm 0.50$ \\
\hline Venom + extract (oral) & $27.11 \pm 2.06$ & $0.42 \pm 0.03^{\mathrm{ns}}$ & $7.85 \pm 0.55$ \\
\hline Venom + extract (i.p) & $23.07 \pm 1.77^{*}$ & $0.47 \pm 0.04$ & $7.12 \pm 0.60^{*}$ \\
\hline Extract $(150 \mathrm{mg} / \mathrm{kg})$ & $20.61 \pm 1.58^{\mathrm{ns}}$ & $0.53 \pm 0.04^{\mathrm{ns}}$ & $6.36 \pm 0.63$ \\
\hline
\end{tabular}

Values are expressed as mean \pm SD of four animals in each group $(p<0.005)$

Statistical comparison: Group II, III, IV and V vs Group I

* - Significant $(\mathrm{p}<0.005)$, ns - not significant 
In the present research work the leaves extract of A. fruticosa was significantly $(\mathrm{p}<0.005)$ neutralized the pharmacological changes which is induced by the Indian saw-scaled viper venom. Hence, these results were clearly exhibits that the plant $A$. fruticosa leaves has the ability to counter act the Indian saw-scaled viper venom.

\section{DISCUSSION}

The most and frequent incidences of snake envenomations are occurs in Asia and Africa. The previously estimated statistical reports indicated that about 5 million snake bite cases are occur in worldwide in every year, which causing about 1,00,000 deaths of victims. On an average, nearly 2,00,000 persons are being as victim to snakebites every year in India among them about 35,000 to 50,000 die because of the snakebite [17]. The snakebite is characterized as a common medical emergency and it was underestimated public health problem which causing a significant morbidity and mortality in worldwide particularly tropical countries. There are about 216 species of snakes in India, among them around 52 snakes species are known as poisonous. The major families of poisonous snakes in India are Elapidae which includes common cobra, king cobra and common krait, Viperidae which includes the saw-scaled viper, Russell's viper and pit viper; and Hydrophidae [18].

In the present study, the antisnake venom activity of leaves extract of A.fruticosa was evaluated using envenomed Wistar albino rats against the Indian saw-scaled viper. The snake envenoming was one of the serious public problem among the rural populations of tropical countries of South Asia particularly in India where the access to the antisnake venom serum was restricted and lesser availability. The snakebite often leads to the death of victims, in other cases the severe tissue loss and amputations also recorded [19].

The effect of ethanolic extract of A. fruticosa leaves on hematological parameters of the experimental rats was determined by the acute toxicity study for the optimum dose fixation of the plant extract. In acute toxicity study, the four different concentrations $(50-200 \mathrm{mg} / \mathrm{kg}$ ) of ethanolic extract of A. fruticosa leaves were treated to the rats by both oral administration and intra peritoneal (i.p.) administration. In both experiments, up to the $150 \mathrm{mg} / \mathrm{kg}$ of ethanolic extract of $A$. fruticosa leaves does not showed any significant $(\mathrm{p}<0.005)$ changes or very mild changes only showed in the hematological parameters of experimental rats when compared to the $200 \mathrm{mg} / \mathrm{kg}$ (Table 1 and Table 2). Hence, the $150 \mathrm{mg} / \mathrm{kg}$ of ethanolic extract of $A$. fruticosa leaves was selected as an optimum dose. This result was supported by the previous findings of Dongmo [20].

The venom of viper snakes was characterized as a hemotoxic category which mainly targets the blood system and often leads to defect in coagulation, fibrinolysis and thrombosis. The viper snake venom also results the local tissue necrosis which is due to the combined cytotoxic effects of the snake venom [21]. In the present study, the saw-scaled viper venom $(60 \mu 1 / \mathrm{ml})$ injected group of rats showed the significantly $(\mathrm{p}<0.005)$ reduced level of blood components such as RBC, hemoglobin and increased level of WBC. Whereas, the administration of snake venom which is preincubated with the extract for 30 min at room temperature was significantly $(\mathrm{p}<0.005)$ increased the $\mathrm{RBC}$ and hemoglobin level and decreased the WBC leaves in the blood of experimental rats (Table 3 ). The administration of extract by orally after the venom injection also showed a significant $(\mathrm{p}<0.005)$ activity. This results was demonstrates that the ethanolic extract of $A$. fruticosa leaves was significantly reduced the toxic effects which is induced by the snake venom.

The saw-scaled viper snake is responsible for more than $80 \%$ of the total venomous bites in some geographical areas of India. The ecchymosis which present in the saw-scaled viper venom is rising the clotting time or bleeding time, hematological complications, local pain and edema. These pharmacological symptoms can help in identifying an Echis carinatus bite is victims [22]. The untreated $E$. carinatus envenomation may be involved in multiple organ failure and the patient may suffer from hematuria, melena, renal failure, hemorrhage, anemia and hypotension and some case reports have indicated myocardial ischemia following viper bites [23]. In concurrence with the yielding of highly toxic venom, makes the Echis species a common cause of injurious or fatal snakebite in the geographical regions where they occupy [24].

The administration of saw-scaled viper venom in experimental rats was resulted the significant $(\mathrm{p}<0.005)$ decrease in the level of liver function marker enzymes such at AST, ALP, ACP and $\gamma$-GT (Table 4). The treatment with the ethanolic extract of $A$. fruticosa leaves was significantly $(\mathrm{p}<0.005)$ increased the liver function markers enzymes level in the envenomed experimental rats. Hence, this could be mentioned the the extract was significantly $(\mathrm{p}<0.005)$ reduced the liver toxicity which is induced by the saw-scaled viper venom. The saw-scaled viper venom injected experimental rats was showed the significantly $(\mathrm{p}<0.005)$ increased level of renal function markers such at creatinine, uric acid and blood urea nitrogen (BUN) which may be because of the renal toxicity of snake venom (Table 5). The administration of ethanolic extract of A. fruticosa leaves was significantly $(\mathrm{p}<0.005)$ decreased the renal function markers in the experimental rats. This ability may be due to the protective ethanolic extract of $A$. fruticosa leaves on renal function. 
The intravenous administration of animal derived (mostly horse or sheep) antivenoms is the mainstay and the only specific treatment of snake bite envenoming with different restrictions on their usage [25]. Anaphylaxis and serum sickness are the major concern with many of the antivenom preparations. These hypersensitivity reactions are mainly caused by the foreign animal proteins present in the antivenom and the probability of a reaction depends partly on the type of antivenom, their manufacturing and concentrating process, and the dose used [26]. So there is a need for generation of new antivenom which should be pharmaceutically safer, cost effective and free of allergic reactions. Though antisnake venom serum is the only therapeutic remedy available for treating the victims till date, much scientific attention has also been given to the identification and isolation of plant derived principles for the treatment of snakebite victims during last two decades. As such use of the medicinal plants for the treatment of snakebite poisoning is a common and age old practice. Many plants are reported to inactivate snake venoms. Search for the exact antidotal combination for treating snakebite victims goes very far behind in the history of Indian Medical Services [27], [28]. In the present scientific investigation, the observed results are clearly demonstrates that the plant $A$. fruticosa leaves was effectively counter acted the Indian saw-scaled viper venom in the experimental rats. The $A$. fruticosa plant was already reported as it was a reservoir of highest number of phtochemicals and this plant has the ability to inhibit the toxic enzymes which is present in the Indian saw-scaled viper venom [29].

\section{CONCLUSION}

Based on the finding of the present research work, this can be concluded as the plant A. fruticosa leaves were effectively neutralized the Indian saw-scaled viper venom in experimental rats. In the saw-scaled viper venom injected rats demonstrated the severe pharmacological effects and these effects were effectively neutralized by the ethanolic extract of A. fruticosa leaves. Hence, the further research in this plant may give a perfect lead to the development of novel antisnake venom compounds which may effective against the snake venom.

\section{REFERENCE}

[1]. Slagboom J, Kool J, Harrison RA, Casewell NR. Haemotoxic snake venoms: their functional activity, impact on snakebite victims and pharmaceutical promise. Br J Haematol, 2017; 177: 947-959.

[2]. Kini RM, Fox JW. Milestones and future prospects in snakevenom research. Toxicon, 2013; 62: 1-2.24.

[3]. Fatima LD, Fatah C. Pathophysiological and pharmacological effects of snake venom components: molecular targets. J Clin Toxicol, 2014; 4: 19.

[4]. Fahmi L, Makran B, Boussadda L, Lkhider M, Ghalim N. Haemostasis disorders caused by envenomation by Cerastes cerastes and Macrovipera mauritanica vipers. Toxicon, 2016; 116: 43-48.

[5]. Gomes A, Das R, Sarkhel S, Mishra R, Mukherjee S, Bhattacharya S. Herbs and Herbal constituent active against snake bite. Indian J Exp Biol, 2010; 48: 865-878.

[6]. Warrell DA, Gutierrez JM, Calvete JJ, Williams D. New approaches and technologies of venomics to meet the challenge of human envenoming by snakebites in India. Indian J Med Res, 2013; 138: 38-59.

[7]. Kanojia A, Chaudhari KS, Gothecha VK. Medicinal plants active against snake envenomation. Int J Res Ayurveda Pharm, 2012; 3(3); 363-6.

[8]. Bibi S, Sultana J, Sultana H, Malik RN. Ethnobotanical uses of medicinal plants in the highlands of Soan Valley, Salt Range, Pakistan. J Ethnopharmacol, 2014; 155: 352-61.

[9]. Sripathi SK, Uma S. Ethnobotanical documentation of a few medicinal plants in the Agasthiayamalai region of Tirunelveli district India. Ethnobot Leaflet, 2010; 14: 173-181.

[10]. Chakravarthy S, Jogen CK. Preliminary phytochemical screening and acute oral toxicity study of the flower of Phylgacanthus hyrsiflorus Nees in albino mice. Int Res J Pharm, 2012; 3: 293- 295.

[11]. Anaswara Krishnan S, Dileepkumar R, Achuthsankar SN, Oommen VO. Studies on neutralizing effect of Ophiorrhiza mungos root extract against Daboia russelii venom. J Ethnopharmacol, 2014; 151: 543-547.

[12]. Reitman S, Frankel S. A colorimetric method for the determination of serum glutamic oxaloacetic and glutamic pyruvic transaminase. Am J Clin Pathol, 1957; 28(1): 56-63.

[13]. King E. Armstrong AR. Determination of serum and bile phosphatase activity. Can Med Assoc J, 1934; 31(4): $376-381$.

[14]. Rosalki SB, Rai D. Serum gamaglutamyl transpeptidase activity in alcoholism. Clin Cem Acta, 1972; 39: 41-47.

[15]. Kind PRN, King EJ. Estimation of plasma phosphatase by determination of hydrolysed phenol with aminoantipyrine. J Clin Path, 1954; 7: 322326.

[16]. Varley JM, Chapman P, McGown G, Thorncroft M, White GRM, Greaves MJ, Scott D. Genetic and functional studies of a germline TP53 splicing mutation in a Li-Fraumeni-like family. Oncogene, 1998; 16: 3291-3298.

[17]. Bhalla G, Mhaskar D, Agarwal A. A study of clinical profile of snake bite at a tertiary care centre. Toxicol Int, 2014; 21(2): $203-8$.

[18]. Kshisagar VY, Ahmed M, Colaco SM. Clinical profile of snake bite in children in rural India Iran J Pediatr, 2013; 23(6): 632-6.

[19]. Maduwage K, Isbister GK. Current treatment for venom-Induced consumption coagulopathy resulting from snakebite. PLoS Negl Trop Dis, 2014; 8(10): 3220.

[20]. Dongmo OLM, Epoh J, Tadjoua HT, Yousuf S, Telefo PB, Tapondjou A, Coudhary MI. Acute and sub-acute toxicity of the aqueous extract from the stem bark of Tetrapleura tetrapteura Taub. (Fabaceae) in mice and rats. J Ethnopharmacol, 2019; 236: 42-49. 
[21]. Boyer L, Alagon A, Fry BG, Jackson TNW, Sunagar K, Chippaux JP. Signs, symptoms and treatment of envenomation. In: Fry, B.G. (Ed.), Venomous Reptiles and Their Toxins: Evolutionary, Pathophysiological and Biodiscovery Implications. Oxford University Press, New York, $2015 ; 32-60$.

[22]. Lakhotia M, Kothari D, Choudhary DR, Sharma S, Jain P. A case of saw-scale viper snakebite presenting as pleuro-pericardial haemorrhage. J Indian Acad Clin Med, 2002; 3: 392-4.

[23]. Maheshwari M, Mittal SR. Acute myocardial infarction complicating snakebite. J Assoc Physicians India, 2004; 52: 63-4.

[24]. Habib AG, Warrell DA. Antivenom therapy of carpet viper (Echis ocellatus) envenoming: effectiveness and strategies for delivery in West Africa. Toxicon, 2013; 69: 82-89.

[25]. Gutierrez JMR, David Theakston G, David Warrell A. Confronting the neglected problem of snake bite envenoming: the need for a global partnership. PloS Medicine, 2006; 3: 1-5.

[26]. Devi CM, Bai MV, Lal AV, Umashankar PR, Krishnan LK. An improved method for isolation of anti-viper venom antibodies from chicken egg yolk. J Biochem Biophys Methods, 2002; 51:129-38.

[27]. Jobin A, Neeta R. New Aspects for Treatment of Snake Bite: A Review. Int Res J Pharm, 2012; 3(11): 1-5.

[28]. Fattepur SR, Gawade SP. Preliminary screening of herbal plant extracts for anti-venom activity against common sea snake (Enhydrina schistosa) poisoning. Pharmacogn Mag, 2007; 3: 56-60.

[29]. Malathi R, Sivakumar D, Chandrasekar S. Studies on pharmacological and biochemical effects of Indian saw-scaled viper venom and its inhibition by Acalypha fruticosa leaves extract. J Pharmacog Phytochem, 2019; 8(1): 2335-2346. 